\title{
Further records of Callinectes sapidus (Rathbun, 1896) (Decapoda, Brachyura, Portunidae) in the Strait of Sicily
}

\author{
Fabio Falsone ${ }^{1}$, Danilo Scannella ${ }^{1 *}$, Michele Luca Geraci ${ }^{1,2}$, Sergio Vitale ${ }^{1}$, Giacomo Sardo ${ }^{1}$ and Fabio Fiorentino ${ }^{1}$
}

\begin{abstract}
Five specimens of the invasive American blue crab Callinectes sapidus were caught from October 2018 to December 2019 off the Mazara del Vallo harbour, Strait of Sicily. This note documents further records of the species in the Strait of Sicily and its settlement in the area. In addition, an update of the spatial distribution of $C$. sapidus in the Mediterranean Sea was provided.
\end{abstract}

Keywords: Blue crab, Non-indigenous species, Biodiversity, Trammel net, Small scale fisheries

\section{Introduction}

The Atlantic blue crab, Callinectes sapidus (Rathbun, 1896), is an endemic species of the eastern coast of America living between southern Canada and northern Argentina (Squires 1990). This species is considered an opportunistic and aggressive predator feeding on fishes, molluscs, crustaceans, arthropods, and polychaetes (Gonzalez-Wanguemert and Pujol 2016; Mancinelli et al. 2017a). Additionally, the Atlantic blue crab shows scavenger and cannibalism behaviour, and it can eat algae as well (Kampouris et al. 2019). Being a eurythermal/euryhaline species, the Atlantic blue crab shows a high tolerance to extreme variation in water conditions living in muddy and sandy bottoms of estuaries, lagoons as well as coastal habitats up to $90 \mathrm{~m}$ of depth (Cabal et al. 2006; Benabdi et al. 2019).

Such characteristics make the C. sapidus one of the 100 worst invasive species in the Mediterranean Sea waters (Streftaris and Zenetos 2006).

In the Mediterranean sea, C. sapidus seems to be acclimatized since the mid-twentieth century (Garcia et al. 2018). The exact date of the first record

\footnotetext{
* Correspondence: danilo.scannella@irbim.cnr.it

${ }^{1}$ Institute for Marine Biological Resources and Biotechnology (IRBIM), National Research Council - CNR, Via Luigi Vaccara 61, 91026 Mazara del Vallo, Italy Full list of author information is available at the end of the article
}

of C. sapidus in the Mediterranean sea is unknown due to the misidentification of the species with Portunus segnis and Portunus pelagicus. As reported by Castriota et al. (2012), first verified record in the Mediterranean occurred in 1949 in the northern Adriatic sea. Then the expansion of $C$. sapidus went on almost all the Mediterranean, reaching a stable presence mainly along the northern coast of the basin (Zenetos et al. 2010; Servello et al. 2019; Cerri et al. 2020). Around the Sicilian waters, this species was first recorded in 1970 and 1972 near the harbour of Messina (Cavaliere and Berdar 1975), as well as in 1988-1990, which was recorded in the eastern coast of Sicily by Franceschini et al. (1993) and only recently off the harbour of Licata by Lipej et al. (2018).

Regarding the vector of Mediterranean introduction, three hypotheses were made by different authors: a) natural arrival by adults due to its swimming ability (Galil et al. 2002), b) dispersal of larvae by ballast water (Garcia et al. 2018), c) intent-ional introduction for commercial purposes as it happened in the eastern Mediterranean with its arrival from America in the 1930s (GiordaniSoika 1951). However, to date, none of these three different hypotheses were accepted by the scientific community as permanent explanation.

(c) The Author(s). 2020 Open Access This article is licensed under a Creative Commons Attribution 4.0 International License, which permits use, sharing, adaptation, distribution and reproduction in any medium or format, as long as you give appropriate credit to the original author(s) and the source, provide a link to the Creative Commons licence, and indicate if changes were made. The images or other third party material in this article are included in the article's Creative Commons licence, unless indicated otherwise in a credit line to the material. If material is not included in the article's Creative Commons licence and your intended use is not permitted by statutory regulation or exceeds the permitted use, you will need to obtain permission directly from the copyright holder. To view a copy of this licence, visit http://creativecommons.org/licenses/by/4.0/. 
Taking into account the aim of the target 9 of the Aichi Biodiversity Targets (Strategic plan for biodiversity 2011-2020), "by 2020, invasive alien species and pathways are identified and prioritized, priority species are controlled or eradicated, and measures are in place to manage pathways to prevent their introduction and establishment", each record is crucial to be reported mainly for the species with high rate of invasiveness such as C. sapidus.

In light of the above considerations, this note documents the finding of further five specimens suggesting the successful settlement of C. sapidus in the Strait of Sicily and provides an updated map of all the records as from the one previously summarised by Mancinelli et al. (2017b) and Labrune et al. (2019).

\section{Materials and methods}

Five specimens of C. sapidus were caught during commercial trammel net fishing operations in the waters off the Mazara del Vallo harbour (approximate coordinates $37.642^{\circ} \mathrm{N}, 12.584^{\circ} \mathrm{E}$ ) at about $3 \mathrm{~m}$ depth. The first specimen, which is the second-ever record in the Strait of Sicily, was caught on 3rd October 2018, the second on 14th November, while the remaining three were caught on 11th December 2019.

The first two specimens were photographed and weighed with an accuracy of $0.1 \mathrm{~g}$ (Fig. 1). Carapace length $(\mathrm{CL}, \mathrm{mm}$ - the distance between the centre of the anterior interorbital margin and the centre of the posterior margin) and carapace width (CW, $\mathrm{mm}$ - the maximal distance between the posterior anterolateral spines) of the first two specimens were recorded with a calliper to the lowest millimetre. In contrast, sexual maturity was determined, according to Türeli et al. (2018).

Unfortunately, for the other specimens, it was not possible to collect biological and biometric information because we had only photos provided by the fishers. (Fig. 2). All the specimens were identified, according to Williams (1974). Further, an up-to-date of the Mediterranean species presence record of the Atlantic blue crab was made by using Quantum GIS software. (Fig. 3)

\section{Results and discussion}

The first specimen weighed $328.8 \mathrm{~g}$ and measured 81.5 and $207.5 \mathrm{~mm}$ in $\mathrm{CL}$ and $\mathrm{CW}$, respectively. While the second one weighed $312.5 \mathrm{~g}$ and measured 80 and $197 \mathrm{~mm}$ in CL and CW, respectively. According to Türeli et al. (2018), both blue crabs were adult females (stage IV) with dark orange ovaries. The main features, such as brownish-green dorsal carapace surface with white spots, scattered mostly in its anterior portion, whitish ventral surface, and bright orange chelipeds, were in agreement with the description proposed by Williams (1974) (Fig. 1). Considering that the first record in the Strait of Sicily (i.e., Maltese waters) reported by Schembri and Lanfranco (1984) was a misidentification with Portunus segnis (Crocetta et al. 2015), our findings represent the second record of C. sapidus in the Strait of Sicily being $160 \mathrm{~km}$ westernmost to the first record collected off Licata by Lipej et al. (2018).

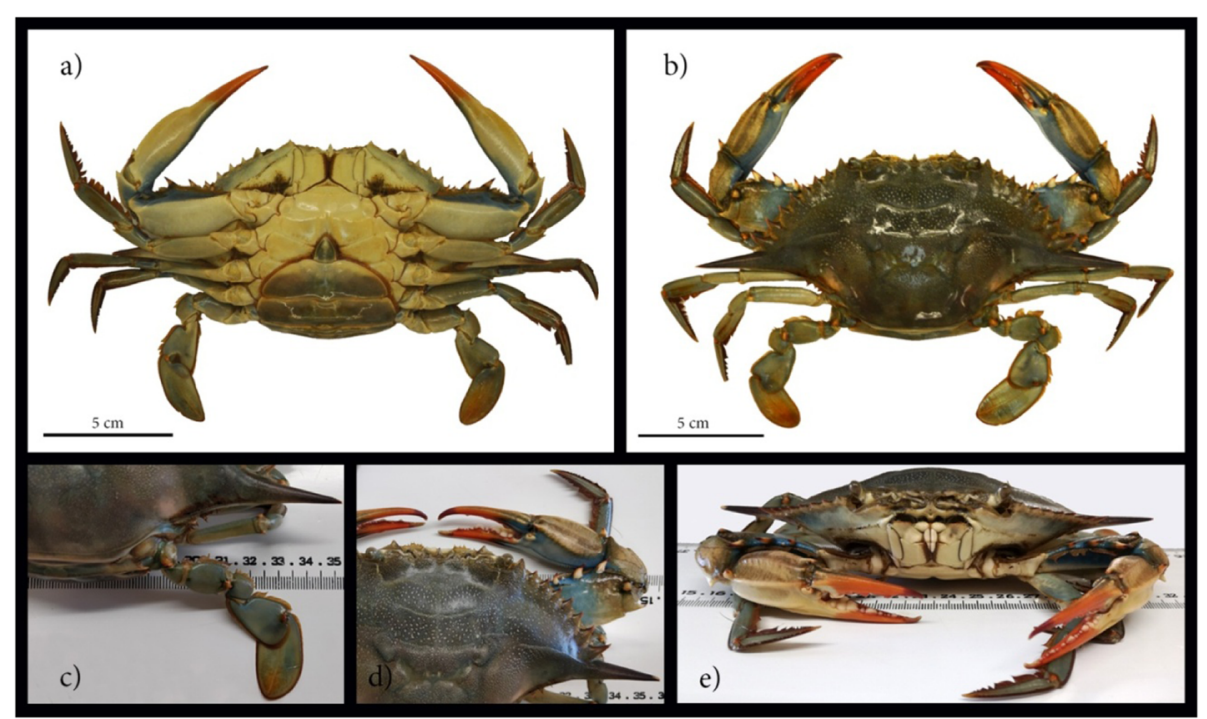

Fig. 1 Callinectes sapidus. The first specimen caught off Mazara del Vallo harbor. a) ventral view with abdomen cavity, b) dorsal view, c) particular of the dactyl, d) details of the antero-lateral and lateral spines and e) frontal view. Scale bar:5 cm 


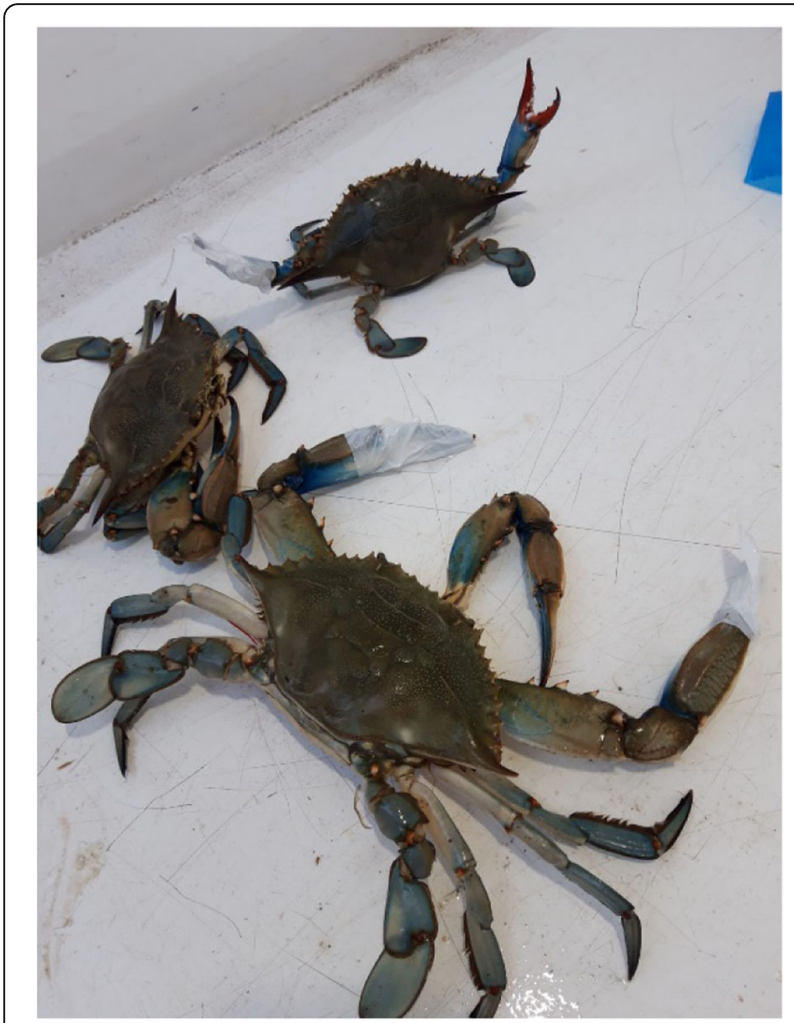

Fig. 2 Three specimens of C. sapidus caught on 11 December 2019

In our opinion, the occurrence of the blue crab in the Strait of Sicily might be due to transport of larvae by ballast waters (Nehring 2011) related to the intense marine traffic in the area (La Loggia et al. 2011; Mangano and Sarà 2017,) or to the biofouling linked both to aquaculture facilities (Montalto et al. 2020) as well as to the Sicilian distant trawlers operating in the Eastern Mediterranean returning to home port. However, available information is not sufficient to provide a definite answer to either one of the two causes of its occurrence in the area. Nevertheless, these records together with the finding of other alien species (e.g. Katsanevakis et al. 2020; Dragičević et al. 2019; Geraci et al. 2018; Scannella et al. 2017) strengthen the hypothesis that the Strait of Sicily plays a key role in the spatial dynamics of alien species. Indeed, this area is characterized by a mesoscale circulation system that might facilitate their spread and arrival (Capodici et al. 2018) as well as by local conditions, such as water temperature, salinity, oxygen and seabed habitat, that can improve their settlement and survival ability (Montalto et al. 2020). Looking at the whole Mediterranean Sea, the Atlantic blue crab is almost ubiquitous in Aegean and Levantine basins and in the last two decades has become common along the Ionian coasts as well as in the Adriatic Sea, with repeated observations in Italy, Croatia, Montenegro, and
Albania (Mancinelli et al. 2017b). In the last years, increasing records of blue crab have also occurred in Sardinian waters as reported by Piras et al. (2019) and in the North-East of the Iberian Peninsula by Fuentes et al. (2019), in Algeria by Benabdi et al. (2019), in Morocco by Oussellam and Hocein (Chartosia et al. 2018) and South-west Sicily (Lipej et al. 2018 and present records), suggesting that the species continues its expansion in the western sector of Mediterranean basin (Fig. 2). According to the available literature (see Fig. 2), it is interesting to note as $C$. sapidus seems to be widely distributed across the whole Mediterranean basin except the coasts of Tunisia and Libya, where the invasive species, native of the Indian Ocean, $P$. segnis, is very abundant in shallow waters with a negative impact on small scale fisheries (Amor et al. 2015). Probably, the absence of C. sapidus in these areas could be due to the limited freshwater supply needed to complete its life cycle. However, considering that most of the distant trawlers of the Mazara fleet operate also in the African shelf of the Strait of Sicily, closer monitoring of the catches off the coast of Tunisia and Libya should be necessary.

Taking into account that American blue crab is one of the 100 'Worst Invasive Alien species in the Mediterranean' (Streftaris and Zenetos 2006), it is crucial to investigate its impact on biodiversity as well as on local fisheries. As for the biodiversity aspect, its colonization might alter the natural equilibrium since that in its native area play a crucial role in ecosystem functions being carnivorous, scavenger, and a voracious predator (Dulčić et al. 2011). Regarding local fisheries, the American blue crab could become a significant commercial resource (e.g., Bilen and Yesilyurt 2014; Manfrin et al. 2015; Abdel-Razek et al. 2006) or it could be the cause of the loss of commercial harvest, damage of fishing nets and fish harvesting difficulties (Amor et al. 2015). In some areas of the Mediterranean, such as Turkey (Bilen and Yesilyurt 2014), the Adriatic Sea (Manfrin et al. 2015), and Egypt (Abdel-Razek et al. 2006), the American blue crabs have become a valuable fishery resource. On the contrary, in Greece, the Blue crab has a poor commercial value (Perdikaris et al. 2016; Mancinelli et al. 2017c; Kevrekidis and Antoniadou 2018).

Regarding the negative effects of C. sapidus, as suggested by Mancinelli et al. (2017a), further studies should be made to understand the nature of impact and the implications for the native species due to its presence. However, as highlighted by several studies, C. sapidus can attack fish and other crustaceans trapped in fishing nets and damage fishing gear (Mancinelli et al. 2017b; Garcia et al. 2018). 


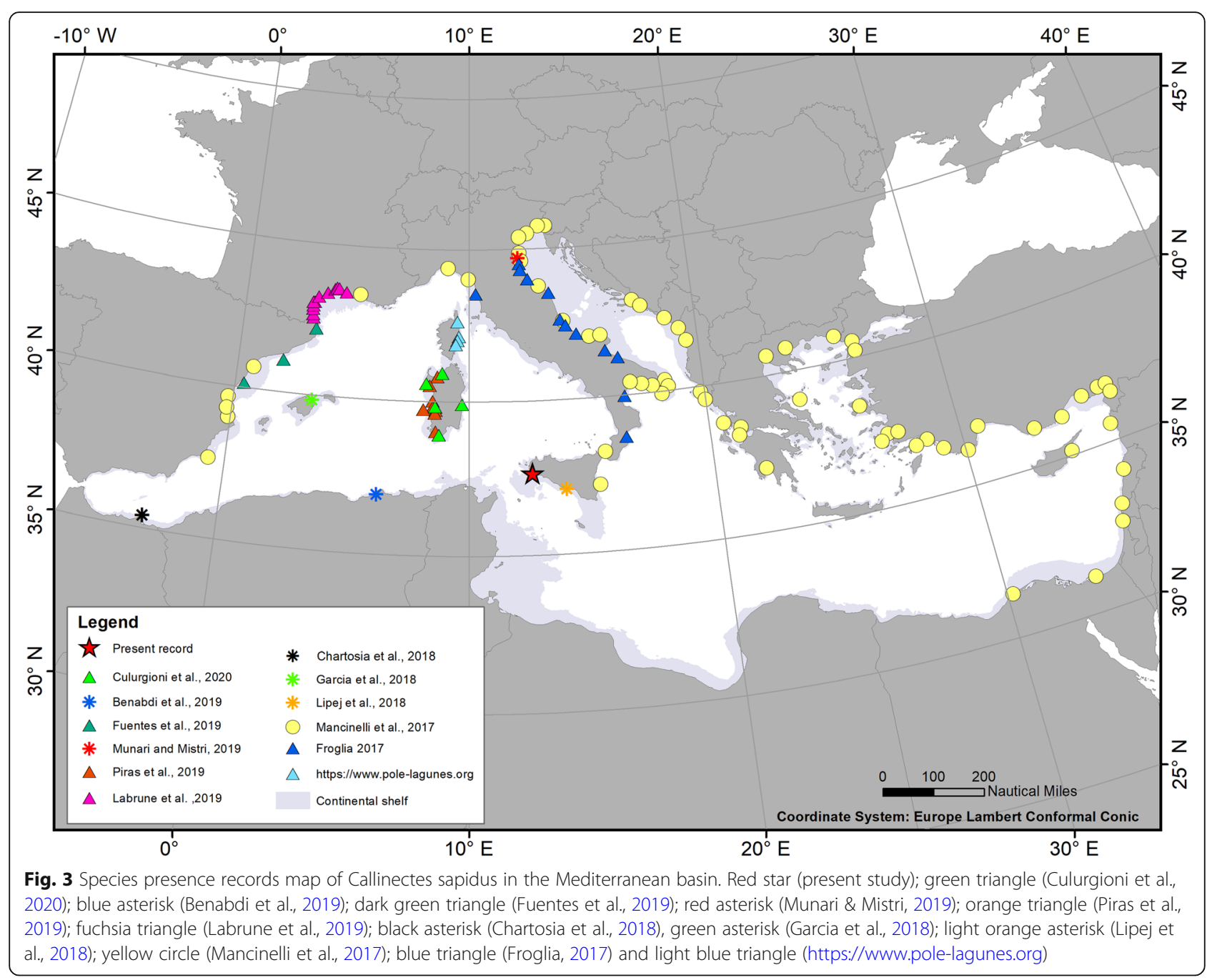

Therefore, its voracity and aggressive behaviour might gradually alter the native Mediterranean biodiversity with socio-economic implications.

\section{Conclusions}

These findings confirm the ongoing expansion and settlement of $C$. sapidus in the northern part of the Strait of Sicily, central Mediterranean Basin. Considering the high spread rate of the species and its aggressive behaviour, it could soon colonize the Sicilian coasts, becoming a serious problem for a crucial socio-economic sector of the area such as artisanal fisheries. It is important to remember in this respect that the similar species $P$. segnis is causing a real problem for small scale fisheries in the Gulf of Gabes by damaging catches and trammel nets with a consequent loss of $70 \%$ of the fishers' income (Khamassi et al. 2019).

Considering that the Strait of Sicily is one of the most important fishing areas for demersal resources in the Mediterranean (Milisenda et al. 2017), a specific monitoring programme will be needed to evaluate the potential harmful impact of this alien species and to activate early warning and prevention actions. Currently, as reported by Culurgioni et al. (2020) for the Sardinian waters, also in the northern part of Sicily, the spread of C. sapidus is monitored thanks to a fruitful collaboration among researchers, and both professional and recreational fishers. This collaboration, together with the Local Ecological Knowledge (LEK) approach (Azzurro et al. 2019), could represent a powerful tool to understand the future implications derived from the presence and potential settlement of $C$. sapidus in the Strait of Sicily.

\section{Acknowledgements}

Special thanks to the Mazara del Vallo's fisherman who provided sample for this marine record.

\section{Authors' contributions}

FFA, DS and MLG performed the laboratory analysis. FFA, FF and MLG conceptualized the research. GS, SV and DS analysed the data. FFA, DS and GS drafted the manuscript, whilst SV and FF edited and reviewed the 
manuscript. All authors participated and commented in various aspects of discussing the results to achieve the final manuscript. The author(s) read and approved the final manuscript.

\section{Funding}

Financial support for the current study was provided by European Data Collection Framework (DCF) - module CampBiol.

\section{Availability of data and materials}

The datasets used and/or analysed during the current study are available from the corresponding author.

\section{Ethics approval and consent to participate}

Not applicable.

\section{Consent for publication}

Not applicable.

\section{Competing interests}

The authors declare that they have no competing interests.

\section{Author details}

'Institute for Marine Biological Resources and Biotechnology (IRBIM), National Research Council - CNR, Via Luigi Vaccara 61, 91026 Mazara del Vallo, Italy. ${ }^{2}$ Department of Biological, Geological and Environmental Sciences (BiGeA) Marine biology and fisheries laboratory of Fano (PU), University of Bologna (BO), Bologna, Italy.

\section{Received: 9 October 2019 Accepted: 1 July 2020}

\section{Published online: 03 August 2020}

\section{References}

Abdel-Razek FA, Ismaiel M, Ameran MAA. Occurrence of the blue crab Callinectes sapidus, Rathbun, 1896, and its fisheries biology in Bardawil lagoon, Sinai peninsula, Egypt. Egypt J Aquat Res 2006;42:223-229; https://doi.org/https:// doi.org/10.1016/j.ejar.2016.04.005.

Amor KOB, Rifi M, Ghanem R, Draeif I, Zaouali J, Souissi JB. Update of alien fauna and new records from Tunisian marine waters. Mediterr Mar Sci 2015;17:124143; http://dx.doi.org/https://doi.org/10.12681/mms.1371.

Azzurro E, Bolognini L, Dragičević B, Drakulović D, Dulčić J, Fanelli E, et al. Detecting the occurrence of indigenous and non-indigenous megafauna through fishermen knowledge: a complementary tool to coastal and port surveys. Mar Pollut Bull 2019;147: 229-236; https://doi.org/https://doi.org/10. 1016/j.marpolbul.2018.01.016.

Benabdi M, Belmahi AE, Grimes S. First record of the Atlantic blue crab Callinectes sapidus Rathbun, 1896 (Decapoda: Brachyura: Portunidae) in Algerian coastal waters (southwestern Mediterranean). Biolnvasions Records 2019;8:119-122; https://doi.org/https://doi.org/10.3391/bir.2019.8.1.13.

Bilen CT, Yesilyurt IN. Growth of blue crab, Callinectes sapidus, in the Yumurtalik cove, Turkey: a molt process approach. Cent Eur J Biol 2014;9:49-57; https:// doi.org/https://doi.org/10.2478/s11535-013-0170-9.

Cabal J, Millán AP, Arronte JC. A new record of Callinectes sapidus Rathbun, 1896 (Crustacea: Decapoda: Brachyura) from the Cantabrian Sea, Bay of Biscay, Spain. Aquat Invasions. 2006;1:186-7. https://doi.org/10.3391/ai.2006.1.3.14.

Capodici F, et al. Downscaling hydrodynamics features to depict causes of major productivity of Sicilian-Maltese area and implications for resource management. Sci Total Environ. 2018;628:815-25. https://doi.org/10.1016/j. scitotenv.2018.02.106.

Castriota L, Andaloro F, Costantini R, De Ascentiis A. First record of the Atlantic crab Callinectes sapidus Rathbun, 1896 (Crustacea: Brachyura: Portunidae) in Abruzzi waters, Central Adriatic Sea. Acta Adriat. 2012;53:467-71.

Cavaliere A, Berdar A. Presenza di Callinectes sapidus Rathbun (Decapoda Brachyura) nello Stretto di Messina. Boll Pesca Piscicolt Idrobiol. 1975;30:315-22.

Cerri J, Chiesa S, Bolognini L, Mancinelli G, Grati F, Dragičević B, Dulčic J, Azzurro E, (2020) Using online. questionnaires to assess marine bio-invasions: A demonstration with recreational fishers and the Atlantic blue crab Callinectes sapidus (Rathbun, 1986) along three. Mediterranean countries. Marine Pollution Bulletin 156:111209.

Chartosia N, Anastasiadis D, Bazairi H, Crocetta F, Deidun A, Despalatović M, et al. New Mediterranean Biodiversity Records (July 2018). Mediterr Mar Sci. 2018; 19:398-415. https://doi.org/10.12681/mms.18099.
Crocetta F, Agius D, Balistreri P, Bariche M, Bayhan Y, Çakir M, et al. New Mediterranean Biodiversity Records (October 2015). Mediterr Mar Sci. 2015;16: 682-702; doi: http://dx.doi.org/https://doi.org/10.12681/mms.1477.

Culurgioni J, Diciotti R, Satta CT, Camedda A, de Lucia GA, Pulina S, et al. Distribution of the alien species Callinectes sapidus (Rathbun, 1896) in Sardinian waters (western Mediterranean). Biolnvasions Records. 2020;9:6573. https://doi.org/10.3391/bir.2020.9.1.09.

Dragičević, B, Anadoli, O, Angel, D, Benabdi, M, Bitar, et al. New Mediterranean biodiversity records. Mediterr Mar Sci 2019;20: 645-656. doi: https://doi.org/ https://doi.org/10.12681/mms.20913.

Dulčić J, Tutman P, Matić-Skoko S, Glamuzina B. Six years from first record to population establishment: the case of the blue crab, Callinectes sapidus Rathbun, 1896 (Brachyura, Portunidae) in the Neretva River delta (Southeastern Adriatic Sea, Croatia). Crustaceana (Leiden). 2011;84:1211-20. https:// doi.org/10.1163/156854011X587478

Franceschini G, Andaloro F, Diviacco G. La macrofauna dei fondi strascicabili della Sicilia orientale. II Naturalista Siciliano. 1993;7:311-24.

Froglia C. In: Daladino C, editor. Cambiamenti recenti nella comunità dei crostacei decapodi dell' Adriatico. Atti del convegno II Mare Adriatico e le sue risorse, vol. 268; 2017.

Fuentes MA, Torrent L, Barrera S, Boix D. Rapid invasion of the American blue crab Callinectes sapidus Rathbun, 1896 in the north-east of the Iberian Peninsula. Biolnvasions Records 2019;8:113-118; https://doi.org/https://doi. org/10.3391/bir.2019.8.1.12.

Galil B, Froglia C, Noël P. CIESM Atlas of Exotic Species in the Mediterranean. In: Briand F, editor. Crustaceans: decapods and stomatopods, vol. 2. Monaco: CIESM Publishers; 2002.

Garcia L, Pinya S, Colomar V, París T, Puig M, Rebassa M, Mayol J. The first recorded occurrences of the invasive crab Callinectes sapidus Rathbun, 1896 (Crustacea: Decapoda: Portunidae) in coastal lagoons of the Balearic Islands (Spain). Biolnvasion Records 2018;7:191-196; https://doi.org/https://doi.org/10.3391/bir.2018.7.2.12.

Geraci ML, Scannella D, Falsone F, Colloca F, Vitale S, Rizzo P, et al. Preliminary study on the biological traits of the Por's goatfish Upeneus pori (Chordata: Actinopterygii) off the southern coast of Lampedusa Island (Central Mediterranean). Eur Zool J. 2018;85: 231-41. https:/doi.org/10.1080/24750263.2018.1464218.

Giordani-Soika A. II Neptunus pelagicus (L.) nell'alto Adriatico. Natura. 1951;42:18-20.

Gonzalez-Wanguemert M, Pujol JA. First record of the Atlantic blue crab Callinectes sapidus (Crustacea: Brachyura: Portunidae) in the Segura River mouth (Spain, southwestern Mediterranean Sea). Turkish J Zool. 2016;40:6159. https://doi.org/10.3906/zoo-1511-23.

Kampouris T E, Porter J S, Sanderson W G.. Callinectes sapidus Rathbun, 1896 (Brachyura: Portunidae): an assessment on its diet and foraging behaviour, Thermaikos gulf, NW Aegean Sea, Greece: evidence for ecological and economic impacts. Crustacean Res 2019;48: 23-37; https://doi.org/https://doi. org/10.18353/crustacea.48.0_23.

Katsanevakis S, Poursanidis D, Hoffman R, Rizgalla J, Rothman SB-S. Unpublished Mediterranean records of marine alien and cryptogenic species. Biolnvasions Records 2020; 9: 165-182; https://doi.org/https://doi.org/10.3391/bir.2020.9.2.01.

Kevrekidis K, Antoniadou C. Abundance and population structure of the blue crab Callinectes sapidus (Decapoda, Portunidae) in Thermaikos gulf (Methoni Bay), northern Aegean Sea. Crustaceana 2018;91:641-657; https://doi.org/ https://doi.org/10.1163/15685403-00003795.

Khamassi F, Ghanem R, Khamassi S, Dhifallah F, Ben Souissi J. Socio-economic impacts of the alien invasive crab Portunus segnis (forskål, 1775) in the Gulf of Gabès. Rapp Comm int Mer Médit. 2019:42:253.

La Loggia G, Capodici F, Ciraolo G, Drago A, Maltese A. Monitoring Mediterranean marine pollution using remote sensing and hydrodynamic modeling. Remote Sensing Agric Ecosystems Hydrol. 2011;8174:817416. https://doi.org/10.1117/12.903761.

Labrune C, Amilhat E, Amouroux JM, Jabouin C, Gigou A, Noël P. The arrival of the American blue crab, Callinectes sapidus Rathbun, 1896 (Decapoda: Brachyura: Portunidae), in the Gulf of lions (Mediterranean Sea). Biolnvasions Records. 2019;8(4):876-81.

Lipej L, Acevedo I, Akel E, Anastasopoulou A, Angelidis A, Azzurro E, et al. "New Mediterranean biodiversity records" (march 2017). Mediterr Mar Sci 2018;18: 179-201; http://dx.doi.org/https://doi.org/10.12681/mms.2068.

Mancinelli G, Chainho P, Cilenti L, Falco S, Kapiris K, Katselis G, Ribeiro F. The Atlantic blue crab Callinectes sapidus in southern European coastal waters: distribution, impact and prospective invasion management strategies. Mar Pollut Bull 2017a; 119:5-11; https://doi.org/https://doi.org/10.1016/.marpolbul.2017.02.050. 
Mancinelli G, Chainho P, Cilenti L, Falco S, Kapiris K, Katselis G, Ribeiro F. On the Atlantic blue crab (Callinectes sapidus Rathbun 1896) in southern European coastal waters: time to turn a threat into a resource?. Fish Res 2017c;194:1-8; https://doi.org/https://doi.org/10.1016/j.fishres.2017.05.002.

Mancinelli G, Guerra MT, Alujević K, Raho D, Zotti M, Vizzini S. Trophic flexibility of the Atlantic blue crab Callinectes sapidus in invaded coastal systems of the Apulia region (SE Italy): a stable isotope analysis. Estuar Coast Shelf Sci 2017b; 198:421-431; http://dx.doi.org/https://doi.org/10.1016/j.ecss.2017.03.013.

Manfrin C, Chung J, Turolla E, Giulianini P. First occurrence of Callinectes sapidus (Rathbun, 1896) within the Sacca di Goro (Italy) and surroundings. Check List. 2015;11; doi: http://dx.doi.org/https://doi.org/10.15560/11.3.1640.

Mangano MC, Sarà G. Collating science-based evidence to inform public opinion on the environmental effects of marine drilling platforms in the Mediterranean Sea. J Environ Manag. 2017;188:195-202. https://doi.org/10. 1016/j.jenvman.2016.12.013

Milisenda G, Vitale S, Massi D, Enea M, Gancitano V, Giusto G B. et al. Spatiotemporal composition of discard associated with the deep water rose shrimp fisheries (Parapenaeus longirostris, Lucas 1846) in the south-Central Mediterranean Sea. Mar Sci 2017;18(1):53-63; https://doi.org/https://doi.org/ 10.12681/mms.1787.

Montalto V, Rinaldi A, Ape F, Mangano M, Gristina M, Sarà G, Mirto S. Functional role of biofouling linked to aquaculture facilities in Mediterranean enclosed locations. Aquaculture Environ Interact. 2020;12:11-22. https://doi.org/10. 3354/aei00339.

Munari C, Mistri M. A new record of Callinectes sapidus Rathburn, 1896 along the Emilia-Romagna coast. 50 CONGRESSO DELLA SOCIETÀ ITALIANA DI BIOLOGIA MARINA LIVORNO, 10-14 GIUGNO 2019.

Nehring S. Invasion history and success of the American blue crab Callinectes sapidus Rathbun, 1896 in European and adjacent waters. In: Galil BS, Clark PF, Carlton JT editors. In the Wrong Place - Alien Marine Crustaceans: Distribution, Biology and Impacts Invading Nature - Springer Series in Invasion Ecology. 2011.p. 607-624; https://doi.org/https://doi.org/10.1007/ 978-94-007-0591-3_21.

Perdikaris C, Konstantinidis E, Gouva E, Ergolavou A, Klaoudatos D, Nathanailides C, Paschos I. Occurrence of the invasive crab species Callinectes sapidus Rathbun, 1896, in NW Greece. Walailak J Sci Technol. 2016;13:503-10.

Piras P, Esposito G, Meloni D. On the occurrence of the blue crab Callinectes sapidus (Rathbun, 1896) in Sardinian coastal habitats (Italy): a present threat or a future resource for the regional fishery sector?. Biolnvasions Records 2019;8:134-141; https://doi.org/https://doi.org/10.3391/bir.2019.8.1.15.

Scannella D, Falsone F, Geraci M, Froglia C, Fiorentino F, Giusto G, et al. First report of northern brown shrimp Penaeus aztecus Ives, 1891 in strait of Sicily. Biolnvasions Records. 2017;6:67-72. https://doi.org/10.3391/bir.2017.6.1.11.

Schembri PJ, Lanfranco E. Marine Brachyura (Crustacea: Decapoda: Brachyura) from the Maltese islands and surrounding waters (Central Mediterranean). Centro. 1984;1:21-39.

Servello G, Andaloro F, Azzurro E, Castriota L, Catra M, Chiarore A. et al. Marine alien species in Italy: A contribution to the implementation of descriptor D2 of the marine strategy framework directive. Mediterr Mar Sci. 2019;20:1-48, doi:http://dx.doi.org/https://doi.org/10.12681/mms.18711.

Squires HJ. Decapoda Crustacea of the Atlantic Coast of Canada. Can Bull Fish Aquat Sci. 1990;221:1-532.

Streftaris N, Zenetos A. Alien marine species in the Mediterranean - the 100 'worst Invasives' and their impact. Mediterr Mar Sci 2006;7:87-118; https://doi. org/https://doi.org/10.12681/mms.180.

Türeli C, Yeşilyurt IN, Nevşat IE. Female reproductive pattern of Callinectes sapidus Rathbun, 1896 (Brachyura: Portunidae) in Iskenderun Bay, eastern Mediterranean. Zool Middle East 2018;64: 55-63; https://doi.org/https://doi. org/10.1080/09397140.2017.1388495.

Williams AB. The swimming crabs of the genus Callinectes (Decapoda, Portunidae). Fish Bull. 1974;72:685-798.

Zenetos A, Gofas S, Verlaque M, Cinar M, Garcia Raso J, Bianchi C, et al. (2010) Alien species in the Mediterranean Sea by 2010. A contribution to the application of European Union's marine strategy framework directive (MSFD). Part I. spatial distribution. Mediterranean marine Science. 11:381; https://doi. org/10.12681/mms.87

\section{Publisher's Note}

Springer Nature remains neutral with regard to jurisdictional claims in published maps and institutional affiliations.

\section{Ready to submit your research? Choose BMC and benefit from:}

- fast, convenient online submission

- thorough peer review by experienced researchers in your field

- rapid publication on acceptance

- support for research data, including large and complex data types

- gold Open Access which fosters wider collaboration and increased citations

- maximum visibility for your research: over $100 \mathrm{M}$ website views per year

At BMC, research is always in progress.

Learn more biomedcentral.com/submissions 